\title{
Management Of Lower Limb Vascular Injuries in Ghazi Al Hariri Teaching Hospital/Baghdad 2015
}

\author{
Dr. Ibrahim Ahmed Adnan ( MBChB, FIBMS Th. CVS, FACS ) \\ goodexamin2015@gmail.com \\ Dr. Jalal Jaafar Abdulhussein ( MBChB, FIBMS Th. \& CVS, FACS ) \\ Jalal.alzubaidy2015@gmail.com \\ Dr. Hussein Ali Hamad ( MBChB, DS, CABMS ) \\ gg99ffr@mailru.
}

\begin{abstract}
$\underline{\text { Abstract }}$
Background: lower limb vascular injuries are encountered in a vast number of settings, ranging from blast, bullet, stab wounds injuries, to causes as small as blood sampling procedures. Surgery for vascular repair is sometimes indicated without angiography. Broadly speaking, options for repair after assessment of vasculature include simple vessel wall repair, venous patching, resection with end-to-end anastomosis or with inter-positioning graft, bypass graft, ligation or amputation.
\end{abstract}

Aim: The general objective of this study is to identify the etiology, presentations, management and outcome of lower limb vascular injuries in Ghazi Al Hariri hospital, Baghdad, Iraq, from $1^{\text {st }}$ January 2015 to $31^{\text {st }}$ December 2015 .

Patients and Methods: The study design was retrospective hospital based study and the study population included all patients who referred to the vascular surgery consultation clinic in Ghazi Al Hariri Hospital and to emergency department. Ninety patients had lower limb vascular injuries. Data collected using structured checklist and analyzed.

Results: Eighty-five (94.5\%) were males and five (5.5\%) were females. The most common age at presentation was 21-30 years (50\%), followed by 31-40 (24.4\%). Blast penetrating shell injuries were the highest cause for lower limb vascular injury with incidence rate of 50\%, while second cause is bullet penetrating injuries presented at $40 \%$. Most common artery injured was the popliteal artery (40 patients; $44.4 \%$ ) followed by the femoral artery (29 patients; $32.3 \%$ ). Limb salvage rate was $85 \%$ and mortality rate was $7.8 \%$.

Conclusions: Our results revealed that blast injuries are the most frequent cause of lower extremity vascular injuries in Ghazi Al Hariri hospital at the period of our study. Appropriate intervention and rapid restoration of blood flow is crucial to have a good outcome and is the key to successfully salvage the injured limb. Amputation rate was the highest in patients with popliteal artery injuries. 
Web Site: https://imed.utq.edu.iq

ISSN (Print):1992-92 18, ISSN (Online):1992-92 18

DOI: https://doi.org/10.32792/utq/utjmed/18/2/11

\section{Introduction}

Peripheral vascular injuries constitute 4-6\% of major trauma. Lower limb vascular injuries result in much morbidity and functional deficit if not managed vigorously. An urgent intervention and restoration of blood flow to optimize functional outcome is the key to success. Anatomy of lower limb arterial and venous system shown in figure $1 .^{[1]}$

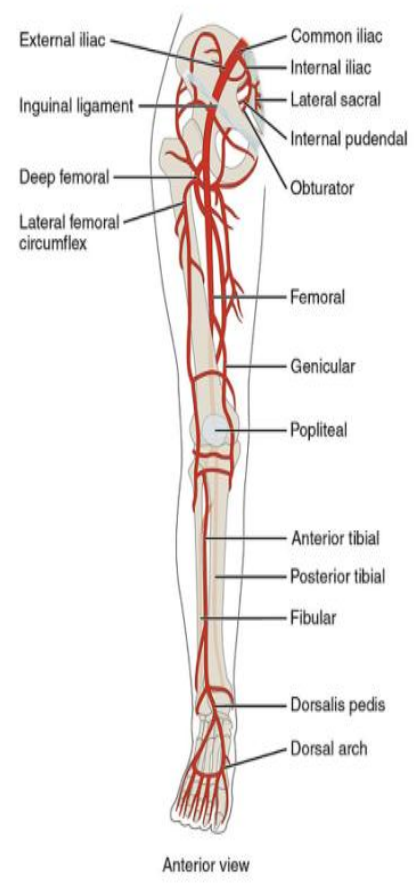

a. Arterial system.

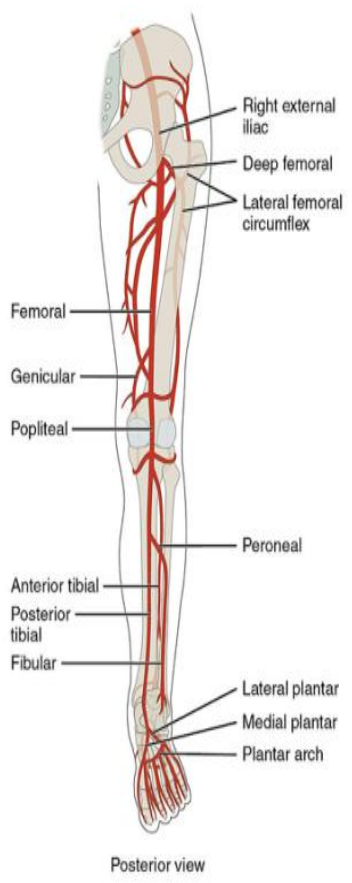

Posterior view

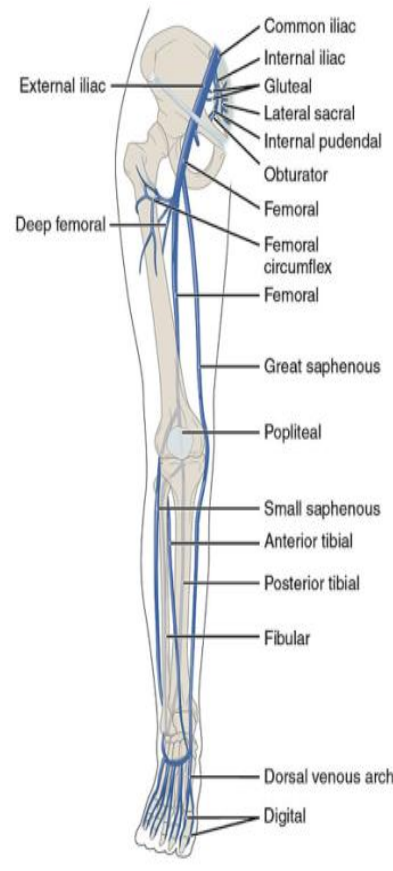

Anterior view

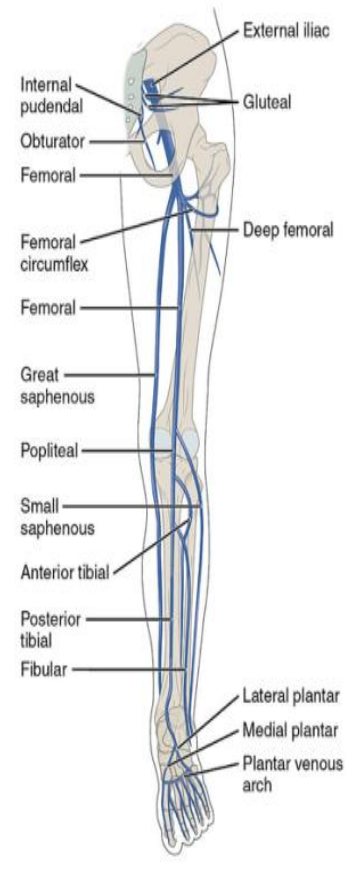

Posterior view Figure $1^{[1]}$

b. Venous system

The American College of Surgeons has classified the causes of vascular injuries usually encountered as:

1) Penetrating wounds following bullet injuries, stab wounds or punctures.

2) Blunt trauma due to joint displacement, bone fracture or contusion adjacent to major arteries.

3) Invasive procedures such as arteriography, cardiac catheterization and balloon angioplasty. ${ }^{\text {[2] }}$ 


\section{Types of Vascular Injury}

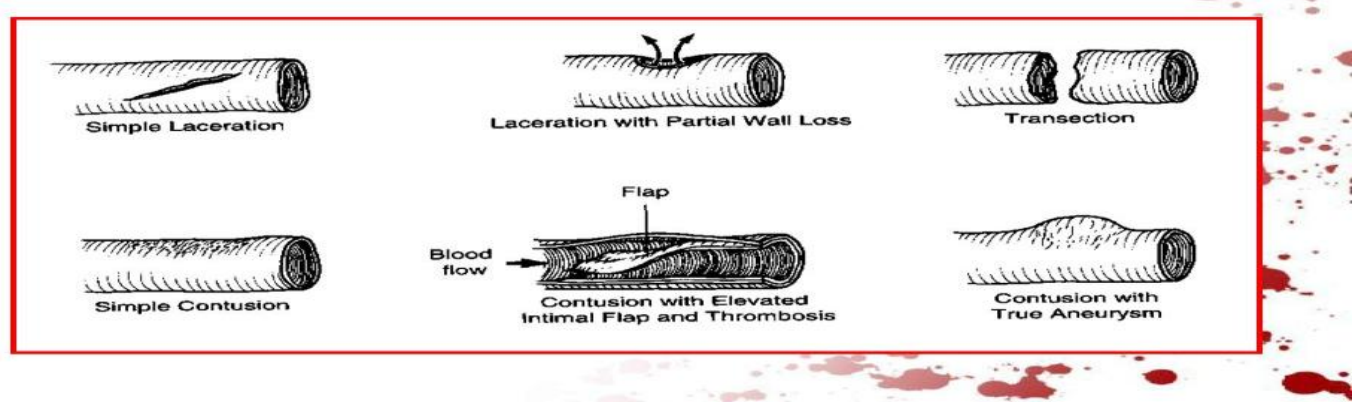

Figure $2^{[3]}$

Although uncommon the complications of hemorrhage and ischemia can be limb threatening and life threatening. Delay allows irreversible ischemic changes to take place and encourages propagation of intravascular thrombosis, which results in eventual loss of function or even limb itself. Venous trauma depends on the type, severity and location of the injury all is important. Some authors have achieved best results with direct repair or simple ligation. The rate of postoperative edema following ligation of vein is variable. ${ }^{[5]}$

\section{Diagnosis}

Physical examination remains the mainstay of diagnosis. Hard signs of vascular injury include thrill, bruit, expanding or pulsatile hematoma, pulsatile hemorrhage, and distal ischemia including lack of pulses or a cold, pale extremity. "'Soft'" signs, suggestive enough of vascular injury to require further workup, include diminished pulses, history of significant hemorrhage, neurologic deficit, and injury proximity to a vessel. Missing a "hard"' sign of vascular injury-a finding mandating surgical intervention - on examination is the most common cause of limb-threatening complications. ${ }^{[10]}$ While proximity alone is a poor predictor of clinically significant injury, with an incidence of $0.6 \%$, a combination of signs increases the likelihood of vascular injury significantly. ${ }^{[11]}$ In penetrating trauma with arterial injury requiring operative intervention, physical exam has a positive predictive value of $100 \%$ and negative predictive value of $99 \% .^{[12]}$

Plain radiography may be indicated to rule out an associated fracture or dislocation. Computed tomography angiography has replaced angiography as first-line imaging for vascular injuries, with a $95 \%$ sensitivity, $90 \%$ specificity and a false negative of 1.3 $\% .^{[13,14]}$ Current indications for angiography include the presence of a thrill or bruit, preserved distal flow despite a significant hematoma, shotgun injuries due to artifact, and multilevel fractures or crush injury because of the risk of multiple injuries to a vessel ${ }^{[15]}$. Duplex ultrasonography, while heavily utilized in non traumatic vascular 
Web Site: https://imed.utq.edu.iq

ISSN (Print):1992-92 18, ISSN (Online):1992-92 18

DOI: https://doi.org/10.32792/utq/utjmed/18/2/11

lesions, is of limited use in trauma. Current practice reflects this, as ultrasonography is used for diagnosis of vascular injury only 3 $\%$ of the time. ${ }^{[16]}$

\section{Principles of Management}

When a vascular injury to the lower extremity has been identified, principles of management are similar regardless of the vessel injured. Documentation of an initial neurovascular exam is critical, particularly in the multiply injured patient with lifethreatening injuries that delay management of the extremity injury. Frequent neurovascular examinations are performed in both the non-operative and post operative setting.

\section{Nonoperative Management}

Non-operative management involves neurovascular examinations in a monitored setting that is capable of frequent checks. Repeat imaging in 3-5 days is performed if needed. Indications for non-operative management include low-velocity injuries causing less than $5 \mathrm{~mm}$ wall disruption with intact distal circulation and no active hemorrhage. ${ }^{[20]}$ Vasospasm usually resolves in 6-8 h. ${ }^{[21]}$ Patients should return for serial surveillance examination and imaging, regardless. Small pseudo-aneurysms may be considered for non-operative management but require close imaging follow-up. ${ }^{[22]}$ Small arteriovenous fistula will always require procedural intervention and nonoperative management is not recommended. ${ }^{[23]}$ Regardless of injury pattern, all vessels undergoing non-operative management require surveillance imaging.

Surgical Management
Email:utjmed@utq.edu.iq

Patients are placed supine on the operating table. The entire injured extremity, the lower abdomen to allow for access to iliac vessels if necessary, and fasciotomy incisions, are included in the operative field. The contralateral limb is also included in the field for potential vein harvest and access to the femoral artery for possible angiography or bypass in complex proximal injuries. A clinician's hand holding direct pressure over a vascular injury is prepped into the field.

Proximal and distal control is obtained before exposing the injury. This sometimes requires an incision distant from the injury. Once the injury is fully exposed and vascular control done, flow is restored via definitive repair. Principles of surgical management include debridement of injured tissue, intra-operative systemic anticoagulation if not contraindicated, local flushing with heparin, a non-stenotic tension-free repair, and adequate tissue coverage of the repair. ${ }^{[24]}$

In the hemodynamically unstable patient, damage control principles apply. Damage control principles in sequence are as follows: (1) abbreviated surgical procedures limited to hemorrhage and contamination control; (2) correction of physiological derangements; (3) definitive surgical procedures. It has been shown that a damage control approach leads to a better outcome in patients with severe injuries that require long operating hours ( $>6$ hours). A temporary prosthetic shunt can be placed and the advantage of this type of bypass is that it allows a sooner return of the patient to return to the ICU for further resuscitation without compromising distal perfusion. The 
Web Site: https://imed.utq.edu.iq

ISSN (Print):1992-92 18, ISSN (Online):1992-92 18

DOI: https://doi.org/10.32792/utq/utjmed/18/2/11

shunt is usually removed $1-2$ days later when the patient is more stable. ${ }^{[25]}$ Selective ligation can be considered if it would not threaten the limb in the patient with multiple sites of life-threatening injury. ${ }^{[26]}$

Once skeletal injuries have been fixed and the patient has been resuscitated, definitive repair is performed. If greater than $50 \%$ of the vessel is injured patch angioplasty with vein or synthetic material or end-to-end anastomosis is preferred if a non-stenotic, tension-free repair can be accomplished. ${ }^{[12]}$ As is often the case, when a tension-free end-to-end anastomosis cannot be accomplished, an interposition graft is appropriate.

Ideally, the contralateral greater saphenous vein is harvested. ${ }^{[27]}$ Proximal and distal balloon thrombectomy is performed before completing the repair if back-bleeding from the vessel is less than satisfactory. Regardless of conduit used, it is essential to maintain adequate tissue coverage of vascular anastomoses. This occasionally requires the involvement of a plastic surgeon to assist with a tissue flap.

Fasciotomy is a mainstay of limb salvage and preserved limb function in the injured patient. Early fasciotomy, during the initial operation or shortly after, reduces the complication and amputation rate fourfold. ${ }^{[28]}$ Failure to perform an adequate fasciotomy at the appropriate time is the most common cause of preventable limb loss. ${ }^{[29]}$ The anterior compartment of the leg is the most commonly missed compartment, leading to foot drop. ${ }^{[28]}$ Fasciotomy should be performed for compartment syndrome,
Email:utjmed@utq.edu.iq

delayed re-vascularization, major vein ligation, and at surgeon discretion. ${ }^{[30]}$

When injuries were due to high-velocity firearms, close range shotguns, or crushing, careful inspection of the missile tract or the injury area was carried out, and tissues of questionable viability were debrided. Tracts created by stab wounds and low-velocity firearms-related injuries were not explored, and only limited skin debridement with primary closure was performed when required. ${ }^{[28]}$

Primary amputation was defined as amputation on admission and without an attempt at re-vascularization. This was carried out whenever limb salvage was deemed impossible. The indications for primary amputation were extremely mangled limbs, fixed skin staining, gangrene, and nonviable superficial posterior compartment plus one other compartment on fasciotomy. Delayed amputations were defined as amputations performed after re-vascularization and within the same admission. ${ }^{[31]}$

\section{Endovascular Management}

Current indications include branch vessel hemorrhage, acute pseudo-aneurysm, arteriovenous fistula, or balloon occlusion for proximal control. ${ }^{[21,32]}$ The only absolute contraindication is an inability to pass a wire. Relative contraindications include hemodynamic instability, uncontrolled hemorrhage, the need to stent over a joint, or 
Web Site: https://imed.utq.edu.iq

ISSN (Print):1992-92 18, ISSN (Online):1992-92 18

DOI: https://doi.org/10.32792/utq/utjmed/18/2/11

stenting in a setting where anticoagulation will be contraindicated.

Embolization has been successfully used in hemorrhage from profunda femoris and tibial level arteries as well as small pseudoaneurysms and arteriovenous fistula in nonessential vessels. ${ }^{[21]}$

\section{Postoperative Management}

At the completion of the operation, a vascular examination should be performed. Doppler examination is a strongly recommended adjunct both intra- and postoperatively. In the hemodynamically stable patient, completion angiography can also be performed, particularly if there was a delay in diagnosis or treatment, there are no palpable pulses, a complex repair was performed, or at surgeon discretion.

Occlusion of distal vessels should be treated with balloon embolectomy, particularly in blunt trauma where shearing forces may disrupt collateral flow. ${ }^{[34]}$ Technical failure such as kinking or undue tension account for the majority of early occlusion. ${ }^{[35]}$ Other causes of early occlusion include intimal flaps, platelet thrombus, and missed compartment syndrome. ${ }^{[36]}$

In patients who do not undergo a fasciotomy at initial operation, serial assessment should include a clinical examination for compartment syndrome. Aspirin should be used for at least 3 months, and as long as possible if feasible, for all patients with an arterial anastomosis. ${ }^{[37]}$ In patients with neurologic deficit, nerve conduction studies can be performed within 6 weeks in order to plan for delayed repair with a nerve graft, usually taken from the sural nerve. ${ }^{[38]}$
Email:utjmed@utq.edu.iq

Early complications include infection, exsanguination, missed or underestimated injury, and compartment syndrome. ${ }^{[39]}$ Even with adequate repair, patients can suffer poor functional outcome, neuralgia, and stigmata of venous hypertension. ${ }^{[40]}$ Chronic complications include pseudo-aneurysm with its concomitant risk of compression, erosion, or emboli when large. ${ }^{[35]}$ Arteriovenous fistula can also develop, with significant fistulae leading to tenderness, edema, steal syndrome, and even congestive heart failure. ${ }^{[41]}$

\section{Aims}

This study aims to assess the management of lower limb vascular injuries, as well as determining epidemiological factors of patients presenting with lower limb vascular injuries, such as gender and age and whether there is a common pattern of presenting complaints with regards to different types of lower limb vascular injuries and associated injuries in Ghazi Al Hariri hospital, Baghdad, Iraq, from $1^{\text {st }}$ of January 2015 to $31^{\text {st }}$ of December 2015.

\section{Patients and Methods}

The study design was a retrospective hospital based study and the study population included all patients that were referred to the vascular surgery consultation clinic in Ghazi Al Hariri Hospital and to the emergency department from January $1^{\text {st }}$, 2015, through December $31^{\text {st }}, 2015$. All the patients of vascular injuries of every age and sex group, military or civilian were included 
ISSN (Print):1992-92 18, ISSN (Online):1992-92 18

DOI: https://doi.org/10.32792/utq/utjmed/18/2/11

in the present study. A total of ninety

was no prospect of return of function with patients were studied. Relevant history was heavily contaminated wounds. obtained from the patient themselves and also from their relatives or witnesses. These patients' demographics such as age and sex and involved vessels, pattern of presentations as well as other data which included etiological factors, treatment offered and outcome of such treatment were analyzed by simple statistics.

Inclusion criteria included the following:

1) All patients admitted to the vascular surgery department with a history of lower limb trauma with suspected vascular injury.

2) Patients with either "soft signs" or "hard signs" of vascular injury.

\section{Exclusion criteria are:}

All patients with traumatic amputations who had severely crushed limbs in whom there

All patients underwent full physical examination and resuscitation according to the principles of the Advanced Trauma and Life Support (ATLS) guidelines of trauma management. The physical signs concerned to be associated with possible significant vascular injury were shock, active bleeding, hematoma (pulsating or expanding), and extensive tissue loss, absent pulses of the lower limbs or neurological deficit. Any active bleeding was controlled by tight bandaging and the wound were examined to determine the location and the mechanism of the injury. Angiography was not always available and instead Doppler study was used and proved to be a useful aid in establishing the diagnosis.

\section{Results}

This study of ninety patients presented with lower limb vascular injuries. Eighty-five patients $(94.5 \%)$ were male patients while only five patients $(5.5 \%)$ were females. There were twentyeight $(31 \%)$ civilian victims and sixty two $(69 \%)$ were military victims. As given in figure 4 and figure 5 . 
Web Site: https://imed.utq.edu.iq

ISSN (Print):1992-92 18, ISSN (Online):1992-92 18

DOI: https://doi.org/10.32792/utq/utjmed/18/2/11

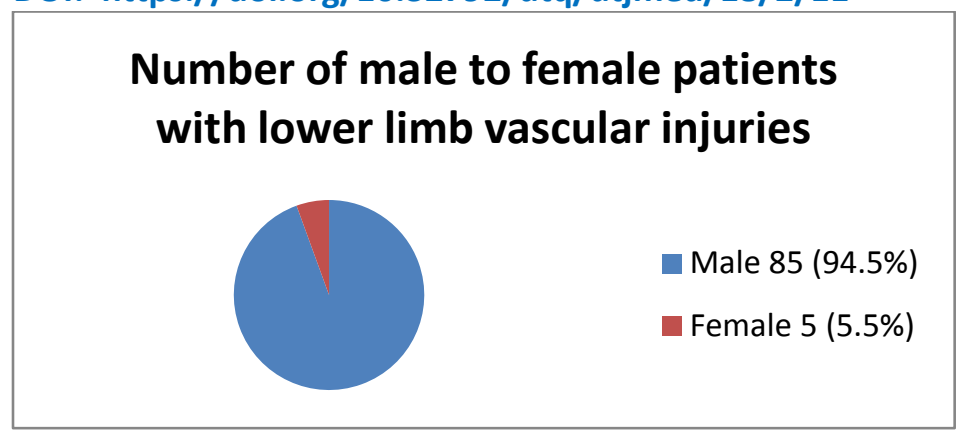

Figure 4

\section{Number of military to civilian patients with lower limb vascular injuries}

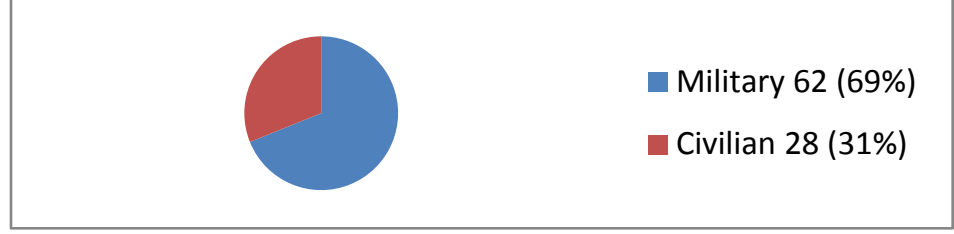

Figure 5

The age at which the highest number of lower limb vascular injuries was 21-30 years old (50\%), followed by $31-40$ years old patients $(24.4 \%)$ and $11-20$ years $(14.4 \%)$ as summarized in Table 1 .

Table 1 Age Distribution

Age (year) No. of Patients Percent

\begin{tabular}{|ccc|}
\hline Less than $\mathbf{1 0}$ & 2 & $2.2 \%$ \\
$\mathbf{1 1}-\mathbf{2 0}$ & 13 & $14.4 \%$ \\
$\mathbf{2 1}-\mathbf{3 0}$ & 45 & $50 \%$ \\
$\mathbf{3 1}-\mathbf{4 0}$ & 22 & $24.4 \%$ \\
$\mathbf{4 1}-\mathbf{5 0}$ & 4 & $4.4 \%$ \\
$\mathbf{5 1}-$ onward & 4 & $4.4 \%$ \\
\hline Total & 90 & $100 \%$ \\
\hline
\end{tabular}

Eighty-four patients suffered penetrating injuries (94\%) and six patients presented with blunt injuries $(6 \%)$. High velocity blast (shell) penetrating injuries were the highest cause for lower limb vascular injuries, with an incidence rate of $50 \%$, while bullet injuries presented at $40 \%$ of the times. Sharp wound penetrating injuries occur in three patients (3.3\%). Only six of patients (6.6\%) suffered vascular injuries due to blunt trauma mainly by road traffic accident in this study, as summarized in Table 2. 
Web Site: https://imed.utq.edu.iq

ISSN (Print):1992-92 18, ISSN (Online):1992-92 18

DOI: https://doi.org/10.32792/utq/utjmed/18/2/11

Table 2 Etiology of lower limb vascular injuries

Mechanism of Injury No. of Patients Percent
Blast (shell) injuries
45
$50 \%$
Bullet injuries
36
$40 \%$
Injury due to sharp
3
$3.3 \%$
instruments
Blunt trauma
Total

$\begin{array}{cc}6 & 6.6 \% \\ 90 & 100 \%\end{array}$

Time of presentation following initial injury was different, the most common presenting complaint was with hard signs of vascular injuries. Sings of arterial insufficiency evidenced by 6 Ps (pain, pulselessness, pallor, paralysis, paraesthesia and poikilothermia) presented in 50 $(55.6 \%)$ patients. Active bleeding at time of presentation was in $27(30 \%)$ patients, five patients had associated hematoma and swelling. In thirteen (14.4\%) patients there were both signs of arterial insufficiency and bleeding at time of presentation.

With Regard to the associated bone, nerve and soft tissue injury; 56 patients had an associated bony injury. Thirty-one (34.4\%) patients had fracture femur, nineteen (21\%) patients had tibial fracture and six $(6.7 \%)$ patients had fibular fracture, as given in figure 6. Eight patients $(9 \%)$ had some sort of neurological deficit (either motor or sensory loss, or both). Twelve (13.3\%) of patients had associated massive soft tissue injuries.

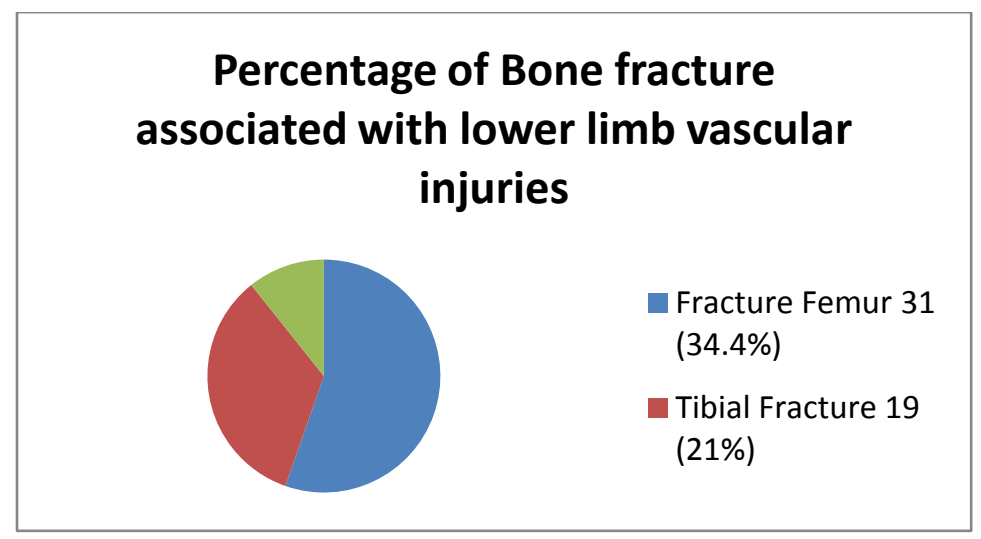

Figure 6

The most common lower limb vascular injury in this study was the popliteal artery that occurs in 40 patients (44.4\%), 36 of them with concomitant popliteal vein injuries. There were three isolated popliteal vein injuries.

The second commonest site of vascular injuries was the femoral artery that occurs in 29 patients $(32.2 \%)$, twenty of these injuries with concomitant femoral vein injuries. There were four isolated femoral vein injuries. One case presented as arteriovenous fistula. 
ISSN (Print):1992-92 18, ISSN (Online):1992-92 18

DOI: https://doi.org/10.32792/utq/utjmed/18/2/11

Tibial level arterial injuries occur in 11 patients (12.2\%), 9 injuries were associated with venous injuries, isolated venous injury at tibial level occur in one case. One case presented as arteriovenous fistula.

There were two patient (2.2\%) presented with external iliac artery injury with concomitant external iliac vein injury. There were two cases presented with multilevel vascular injuries.

Number of arterial injury involved in lower limb vascular injury summarized in figure 7.

\section{Percentage of arterial injury involved in lower limb vascular \\ injuries External Iliac artery $2(2.2 \%)$

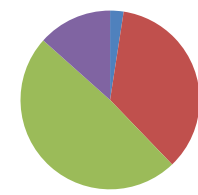 \\ - Femoral Artery 29 \\ (32.2\%) \\ - Popliteal Artery 40 \\ $(44.4 \%)$}

\section{Figure 7}

With regard to the procedure performed of the arterial injuries, 55.6\% repaired by end to end anastomosis, $17.9 \%$ required interposition vein grafts, whereas $3.3 \%$ direct repair. $85 \%$ of tibial level arterial injuries were ligated. As summarized in Table 3.

Table 3: Procedures performed for patients who presented with lower limb arterial injuries.

Venous repair was possible in $8.9 \%$ of the venous injuries; femoral vein repair done in four

\begin{tabular}{cccccc}
\hline Procedure & $\begin{array}{c}\text { External iliac } \\
\text { artery }\end{array}$ & $\begin{array}{c}\text { Femoral } \\
\text { artery }\end{array}$ & $\begin{array}{c}\text { Popliteal } \\
\text { artery }\end{array}$ & $\begin{array}{c}\text { Tibial level } \\
\text { arteries }\end{array}$ & Total \\
\hline $\begin{array}{c}\text { End to end } \\
\text { anastomosis }\end{array}$ & 0 & 24 & 26 & 0 & 50 \\
$\begin{array}{c}\text { Autogenous } \\
\text { bypass graft }\end{array}$ & 1 & 2 & 12 & 1 & 16 \\
$\begin{array}{c}\text { Simple vessel } \\
\text { wall repair }\end{array}$ & 0 & 1 & 1 & 1 & 3 \\
$\begin{array}{c}\text { Vessel } \\
\text { ligation }\end{array}$ & 1 & 1 & 1 & 9 & 12 \\
$\begin{array}{c}\text { Aneurysmec- } \\
\text {-omy }\end{array}$ & 0 & 1 & 0 & 0 & 1 \\
Total & 2 & 29 & 40 & 11 & 82 \\
\hline
\end{tabular}

patients and popliteal vein repair also done in four patients mostly by direct vein repair. The remaining venous injuries at all levels were ligated. The fasciotomy rate for this study was $47.8 \%$ (43 fasciotomies).Postoperatively, lower limb edema occurs in 4.4\%, wound infection occurs in $10 \%$ of patients and secondary bleeding occurs in one patient due to associated wound infection. The limb salvage rate was $85 \%$, and amputation rate was $15 \%$. Amputation rate was highest in patients with popliteal artery injuries $9 \%$ followed by superficial femoral artery injuries $4.5 \%$. Seven of patients $(7.8 \%)$ were died post operatively. 


\section{Discussion}

Vascular injuries account for $2 \%$ of all casualties ${ }^{[42]}$. In this study there was a high ratio of male to female suffers from lower limb vascular injuries (17:1). The most age group affected by lower limb vascular injuries is (21-30) years at $50 \%$; this can logically be explained by young male higher activity making them more liable to trauma and violence. These results are close to the result of other local studies (Muhder study ${ }^{[47]}$ and Jassim study ${ }^{[48]}$ )

Eighty-four patients suffered penetrating lower limb vascular injuries at $(93.3 \%)$ followed by six patients presented with blunt lower limb vascular injury at $(6.7 \%)$. Blast (shell) penetrating injuries were the highest cause for lower limb vascular injuries, with an incidence rate of $50 \%$, while bullet injuries presented at $40 \%$ of the times; most of victims are military at $69 \%$ and the remaining are civilian at $31 \%$. This mode of trauma (blast and bullet injuries) and high military ratio explained by our country situation of war and associated explosions. These results are similar to local Jassim study in that $85 \%$ of vascular injuries are penetrating and $14 \%$ caused by blunt trauma. In Iran (Mohammad R. RASOULI) et al. study ${ }^{[46]}$ the most common cause of lower limb vascular injuries was blunt trauma at $62.2 \%$.

Time of presentation following initial injury was different, the most common presenting complaint was with hard signs of vascular injuries. Sings of arterial insufficiency evidenced by 6 Ps (pain, pulselessness, pallor, paralysis, paraesthesia and poikilothermia) were the commonest hard signs that presented in $50(55.6 \%)$ patients followed by active bleeding that presented in $27(30 \%)$ patients. The severity of tissue ischemia depends not only on its duration but also on the level of arterial injury, extent of soft tissue damage, and the efficiency of collateral circulation. ${ }^{[43]}$ That it is more relevant to identify signs of severe ischemia such as compartmentization or loss of sensation or function than to rely on the absolute ischemia time for predicting outcome. ${ }^{[44]}$

The important goal in the management of lower limb vascular injury is lifesaving followed by limb salvage. ${ }^{[45]}$ The decision to take the patient to the operating room depends on the presence of the hard signs and soft signs of vascular injury. The patient that presented with the hard signs of vascular injury was immediately resuscitated and had been taken to the operating room for exploration. Those patients that presented with soft signs of vascular injury were delayed until full evaluation done. Local use of heparin was mostly used during vascular repair; systemic use of heparin in some cases was depending on the clinical judgment.

The commonest lower limb arterial injury in this study was the popliteal artery $(44.4 \%)$ followed by femoral artery (32.2\%), R. RASOULI et al. found that the most common lower limb arterial injury was in the femoral artery (21\%) followed by the 
Web Site: https://imed.utq.edu.iq

ISSN (Print):1992-92 18, ISSN (Online):1992-92 18

DOI: https://doi.org/10.32792/utq/utjmed/18/2/11

popliteal artery (20\%), this difference can be explained by the mode of trauma. Arterial repair by end to end anastomosis was done in $55.6 \%$ of patients and an inter-positioning autogenous vein graft was done in $17.8 \%$ of patients. Simple vessel wall repair was carried out in only $3.3 \%$ of the patients. Tibial level arterial injury mostly managed by vessel ligation. In Muhder study arterial repair by end to end anastomosis was done in $57 \%$ of patients and an inter-positioning autogenous vein graft was done in $27 \%$ of patients; in Jassim study arterial repair by end to end anastomosis was done in $40 \%$ of patients and an inter-positioning autogenous vein graft was done in $54 \%$ of patients. None of the different methods used for repair was individually associated with increased risk of limb loss.

Of venous injury, venous repair was possible in $8.8 \%$ of the venous injuries. Femoral vein repair done in four patients and popliteal vein repair also done in four patients mostly by direct vein repair. The remaining venous injuries were ligated. Elevation of the extremity and gentle compression with elastic bandages may limit swelling in the early postoperative period. In Jassim study venous injury repair was done in $40 \%$ of cases; in R. RASOULI et al. study all simultaneous venous injury was ligated. Bone, nerve and soft tissue injuries are the most common associated injuries with lower limb vascular injuries and this also consistent with other studies. Bone injury that occur in $62.2 \%$ of cases mostly managed by fixation before vascular repair unless there was threatening limb ischemia. In Jassim study the percentage of vascular
Email:utjmed@utq.edu.iq

injury associated with bone fracture was $40 \%$.

Soft tissue injuries managed by debridement of the dead tissue and good coverage of affected vessel. Primary nerve injury occurs in $9 \%$ of cases, nerve repair done in some cases and other injuries left for secondary intervention, Jassim study shows $30 \%$ associated nerve injuries; in R. RASOULI et al. study there was $13 \%$ associated nerve injuries.

The fasciotomy rate for this series was $47.8 \%$ (43 fasciotomies). Fasciotomy done in:

1- Combined arterial and venous injury.

2- Delayed presentation.

3- Massive soft tissue injury.

4- Lower limb compartment swelling. The fasciotomy rate for Jassim study was $85 \%$; in R. RASOULI et al. study fasciotomy rate was $28 \%$.

The limb salvage rate was $85 \%$, and amputation rate was $15 \%$. Amputation rate was highest in patients with popliteal artery injuries $9 \%$ followed by femoral artery injuries $4.5 \%$. Most common cause of amputation is delayed presentation which prompted the need for amputation. The amputation rate in Jassim study was $17.5 \%$ and $12.5 \%$ in Muhder study.

The most postoperative complications were wound infection (10\%), limb swelling and edema (4.4), secondary bleeding (1.1\%) and eight patients (9\%) had some sort of neurological deficit (either motor or sensory loss, or both) post operatively. In Jassim study the rate of wound infection was $58 \%$ and the rate of limb edema was $85 \%$; in $\mathrm{R}$. 
Web Site: https://imed.utq.edu.iq

Email:utjmed@utq.edu.iq

ISSN (Print):1992-92 18, ISSN (Online):1992-92 18

DOI: https://doi.org/10.32792/utq/utjmed/18/2/11

RASOULI et al. study the rate of wound infection was $20.6 \%$ and the rate of limb edema was $60.9 \%$.

Seven patients $(7.8 \%)$ were died post operatively mostly due to severity of associated injuries and multi organ failure. The mortality rate in Jassim study was 5\%; the mortality rate in Muhder study was $5.7 \%$; in R. RASOULI et al. study the mortality rate was $5 \%$.

\section{Conclusions:}

- Young males are commonly affected by lower limb vascular injuries.

- Blast and bullet injuries are the commonest cause of lower limb vascular injuries.

- Popliteal artery injury is the commonest arterial vascular injury presented to our center.

- Lower limb injuries are injuries that result in considerable morbidity and lifestyle deterioration if a prompt, energetic and dynamic approach is not carried out.

\section{Recommendations:}

- Intervention and a rapid restoration of blood flow are critical to optimize functional outcome and is key to a successful salvage of both the patient and the limb. Fundamentals of care continue to be an accurate and thorough physical exam, rapid restoration of flow in the damage control setting or to restore perfusion before fixation of skeletal injuries in limb threatening ischemia, liberal and early use of fasciotomy, and after resuscitation, definitive repair with completion interrogation of the repair.

- Knowledge of various complications, including those requiring early return to the operating room, are critical to ensure satisfactory outcome.

- Delayed presentation is the fundamental cause of amputation in our study. The key to avoiding amputations in extremity trauma is to increase the awareness of healthcare professionals with regards to issues concerning the approach, appropriate resuscitation and prompt referral of patients.

\section{References:}

1. National Trauma Data Bank, NTDB Annual report 2015.

2. Feliciano DV, Moore FA, Moore EE, West MA, Davis JW, Caocanour CS, et al. Evaluation and management of peripheral vascular injury part 1. Western Trauma Association/critical decisions in trauma. J Trauma. 2011;70:1551-6. 66

3. Andrikopoulos V, Antoniou I, Panoussis P. Arterial injuries associated with lower-extremity fractures. Cardiovasc Surg. 1995; 3: 15-18. PMID: 7780702

4. Bechara C, Huynh TT, Lin PH. Management of lower extremity arterial injuries. J Cardiovasc Surg (Torino). 2007;48(5):567-79.

5. Doody O, Given MF, Lyon SM. Extremities-indications and techniques for treatment of extremity vascular injuries. Injury. 2008;39(11):1295-303. 
Web Site: https://imed.utq.edu.iq

Email:utjmed@utq.edu.iq

ISSN (Print):1992-92 18, ISSN (Online):1992-92 18

DOI: https://doi.org/10.32792/utq/utjmed/18/2/11

6. DuBose JJ, Savage SA, Fabian TC, Menaker J, Scalea T, Holcomb JB, et al. The American Association for the Surgery of Trauma PROspective Observational Vascular Injury Treatment (PROOVIT) registry: multicenter data on modern vascular injury diagnosis, management, and outcomes. J Trauma Acute Care Surg. 2015;78(2):215-22; discussion 22-3. Observational study on current management of vascular injuries in the US.

7. Berceli SA. Autogenous grafts. In: Cronenwett JL, Johnston KW, editors. Rutherford's vascular surgery. 8th ed. Philadelphia: Elsevier Saunders; 2014. p. 1382-401.

8. Rasmussen TE, Stannard A. Injury to extremities. In: Fischer J, editor. Mastery of surgery. 6th ed. Philadelphia: Lippincott Williams \& Wilkins; 2012. p. 2495-504.

9. Smith LM, Block EF, Buechter KJ, Draughn DC, Watson D, Hedden W. The natural history of extremity venous repair performed for trauma. Am Surg. 1999;65(2):116-20.

10. Hafez HM, Woolgar J, Robbs JV. Lower extremity arterial injury: results of 550 cases and review of risk factors associated with limb loss. J Vasc Surg. 2001;33(6):1212-9.

11. Asensio JA, Kuncir EJ, Garcia-Nunez LM, Petrone P. Femoral vessel injuries: analysis of factors predictive of outcomes. J Am Coll Surg. 2006;203(4):512-20.

12. Doody O, Given MF, Lyon SM. Extremities - indications and techniques for treatment of extremity vascular injuries. Injury. 2008;39(11):1295-303.

13. Gargiulo NJ, Ohki T, Cayne NS, Veith FJ. Endovascular grafts for traumatic vascular lesions. In: Rich NM, Mattox KL, Hirshberg A, editors. Vascular trauma. 2nd ed. Philadelphia: Elsevier Saunders; 2004. p. 207-20.

14. Sise MJ, Shackford SR. Extremity vascular trauma. In: Rich NM, Mattox KL, Wakefield TW, editors. vascular trauma. 2nd ed. Philadelphia: Elsevier Saunders; 2004. p. 353-89.

15. Gonzalez RP, Scott W, Wright A, Phelan HA, Rodning CB. Anatomic location of penetrating lower-extremity trauma predicts compartment syndrome development. Am J Surg 2009;197:371-5.

16. Trooskin SZ, Sclafani S, Winfield J, Duncan AO, Scalea T, Vieux E, et al. The management of vascular injuries of the extremity associated with civilian firearms. Surg Gynecol Obstet. 1993; 176(4):350-4.

17. Martin LC, McKenney MG, Sosa JL, Ginzburg E, Puente I, Sleeman D, et al. Management of lower extremity arterial trauma. J Trauma. 1994;37(4):591-8; discussion 8-9.

18. Houston R IV, Rasmussen TE. Utilization of shunting. In: Dua A, Desai SS, Holcomb JB, Burgess AR, Freischlag JA, editors. Clinical review of vascular trauma. New York: Springer; 2014. p. 355-66.

19. Mullenix PS, Steele SR, Andersen CA, Starnes BW, Salim A, Martin MJ. Limb salvage and outcomes among patients with traumatic popliteal vascular injury: an analysis of the National Trauma Data Bank. J Vasc Surg. 2006;44(1):94-100.

20. Bleabea J, Choudry R. Civilian experience with temporary arterial shunts. In: Eskandari MK, Morasch MD, Pearce WH, Yao JST, editors. Vascular surgery: therapeutic strategies. Shelton: People's Medical Publishing House; 2010. p. 193-202.

21. Branco BC, DuBose JJ, Zhan LX, Hughes JD, Goshima KR, Rhee P, et al. Trends and outcomes of endovascular therapy in the management of civilian vascular injuries. J Vasc Surg. 2014;60(5):1297-307, $307 \mathrm{e} 1$. A review of the outcomes of endovascular management of vascular trauma.

22. Rich NM, Baugh JH, Hughes CW. Acute arterial injuries in Vietnam: 1,000 cases. J Trauma 1970;10:359-69.

23. Fox N, Rajani RR, Bokhari F, Chiu WC, Kerwin A, Seamon MJ, et al. Evaluation and management of penetrating lower extremity arterial trauma: an Eastern Association for the Surgery of Trauma practice management guideline. J Trauma Acute Care Surg. 2012;73(5 Suppl 4):S315-20. Evidenced based guidelines. 
Web Site: https://imed.utq.edu.iq

Email:utjmed@utq.edu.iq

ISSN (Print):1992-92 18, ISSN (Online):1992-92 18

DOI: https://doi.org/10.32792/utq/utjmed/18/2/11

24. Inaba K, Branco BC, Reddy S, Park JJ, Green D, Plurad D, et al. Prospective evaluation of multidetector computed tomography for extremity vascular trauma. J Trauma. 2011;70(4):808-15.

25. Romanoff H, Goldberger S. Combined severe vascular and skeletal trauma. Management and results. J Cardiovasc Surg (Torino). 1979;20(5):493-8.

26. Frykberg ER, Dennis JW, Bishop K, Laneve L, Alexander RH. The reliability of physical examination in the evaluation of penetrating extremity trauma for vascular injury: results at one year. $\mathrm{J}$ Trauma. 1991;31(4):502-11.

27. Sise MJ, Shackford SR. Peripheral vascular injury. In: Mattox KL, Moore EE, Feliciano DV, editors. Trauma. 7th ed. New York: McGraw Hill; 2013. p. 816-49.

28. Fox CJ, Gillespie DL, O’Donnell SD, Rasmussen TE, Goff JM, Johnson CA, et al. Contemporary management of wartime vascular trauma. J Vasc Surg. 2005;41(4):638-44.

29. FrykbergER,DennisJW,BishopK,LaneveL,AlexanderRH.Thereliabilityofphysical examination in the evaluation of penetrating extremity trauma for vascular injury: results at one year. J Trauma. 1991; 31: 502-511. PMID:2020036

30. Kumar NG, Knipp BS, Gillespie DL. Lower extremity vascular trauma. In: Rasmussen TE, Tai NRM, editors. Rich's Vascular Trauma. 3rd ed. Philadelphia: Elsevier; 2015. p. 168-82. Seminal textbook on vascular trauma.

31. Perkins ZB, De'Ath HD, Aylwin C, Brohi K, Walsh M, Tai NR. Epidemiology and outcome of vascular trauma at a British Major Trauma Centre. Eur J Vasc Endovasc Surg. 2012;44(2):203-9.

32. Yelon JA, Scalea TM. Venous injuries of the lower extremities and pelvis: repair versus ligation. J Trauma. 1992;33(4):532-6; discussion 6-8.

33. Johnson CA. management of peripheral vascular trauma. Semin Interv Radiol. 2010;27:38-43.

34. Feliciano DV, Moore EE, West MA, Moore FA, Davis JW, Cocanour CS, et al. Western Trauma Association critical decisions in trauma: evaluation and management of peripheral vascular injury, part II. J Trauma Acute Care Surg. 2013;75(3):391-7. Guidelines for management of vascular trauma.

35. Worni M, Scarborough JM, Gandhi M, Pietrobon R, Shortell CK. Use of endovascular therapy for peripheral arterial lesions: an analysis of the National Trauma Data Bank from 2007 to 2009. Ann Vasc Surg. 2013;27:299-305.

36. White R, Krajcer Z, Johnson M, Williams DM, Bacharach M, O'Malley E. Results of a multicenter trial for the treatment of traumatic vascular injury with a covered stent. J Trauma. 2006;60: 1189-96. Curr Trauma Rep (2015) 1:61-68 67

37. Clouse WD, Rasmussen TE, Peck MA, Eliason JL, Cox MW, Bowser AN, et al. In theater management of vascular injury: two years of the Balad Vascular Registry. J Am Col Surg 2007;204:62532.

38. Lovric Z, Lehner V, Kosic-Lovric L, Wertheimer B. Reconstruction of major arteries of lower extremities after war injuries. Long-term follow up. J Cardiovasc Surg 1996;37:223-7.

39. Franz RW, Shah KJ, Halaharvi D, Franz ET, Hartman JF, Wright ML. A 5-year review of management of lower extremity arterial injuries at an urban level I trauma center. J Vasc Surg. 2011;53: 1604-10.

40. Nanobashvili J, Kopadze T, Tvaladze M, Buachidze T, Nazvlishvili G. War injuries of major extremity arteries. World J Surg 2003;27:134-9.

41. Sfeir R, Khoury G, Kenaan M. Vascular trauma to the lower extremity: the Lebanese war experience. Cardiovasc Surg 1995;3:653-7.

42. Sherif A. Vascular injuries: experience during the Afghanistan War. Int Surg 1992;77:114-7.

43. Nanobashvili J, Kopadze T, Tvaladze M, Buachidze T, Nazvlishvili G. War injuries of major extremity arteries. World J Surg 2003;27:134-9.

44. Starnes BW, Beekley AC, Sebesta JA, Andersen CA, Rush RM Jr. Extremity vascular injuries on the battlefield: tips for surgeons deploying to war. J Trauma 2005;60:432-42. 
Web Site: https://imed.utq.edu.iq

Email:utjmed@utq.edu.iq

ISSN (Print):1992-92 18, ISSN (Online):1992-92 18

DOI: https://doi.org/10.32792/utq/utjmed/18/2/11

45. DeBakeyM,SimeoneFA.Battleinjuriesofthearteries in World War II. An analysis of 2,471 cases. Ann Surg 1946;123:534-79.

46. Mohammad R. RASOULI, Majid MOINI, Ali KHAJI, Pedram HEIDARI, Arash ANVARI et al. Traumatic vascular injuries of the lower extremity: report of the Iranian National Trauma Project.

47. Nazar Al HASSANY, Muhder Hussain study. Femoral artery injury. 2002

48. Faisal HABA, Jassim mohammed study. Popliteal artery injury. 2003

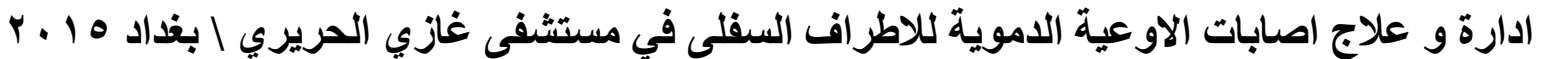

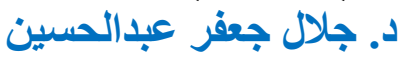

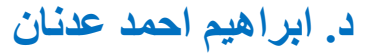

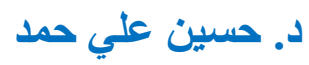

الملخص

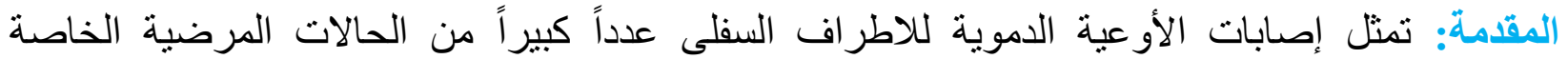

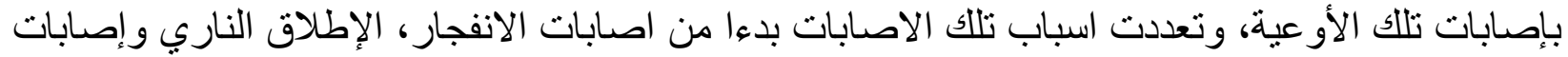

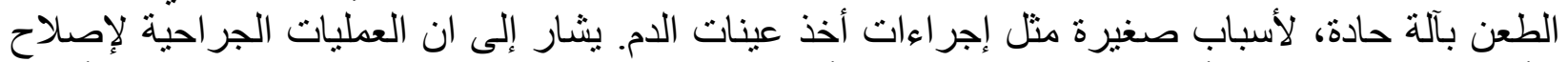

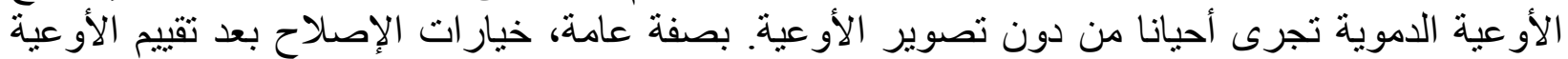

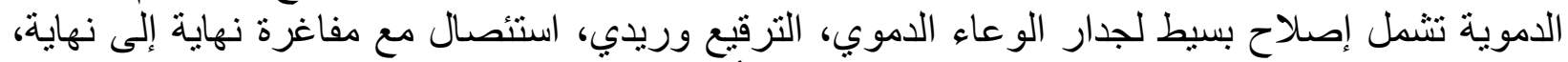
التوصيل او الالتفافية بشريان اصطناعي، وربط الثريان أو البتر.

الهوف من البيث: الهُف العام من هذه الدراسة هو التعرف على المسببات، الأعراض المرضية، طريقة

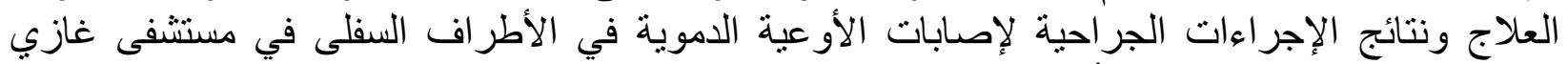

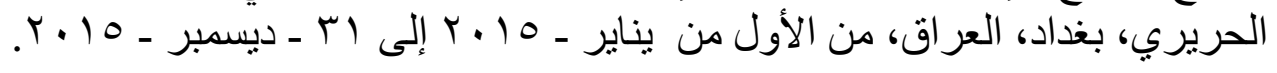

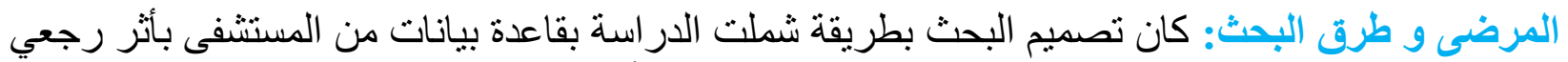

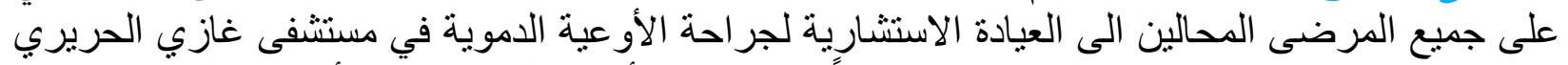

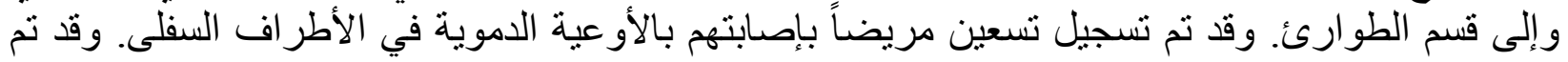

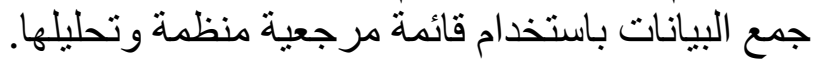

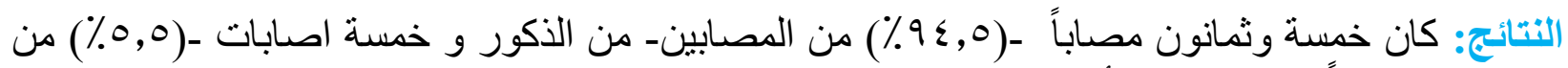

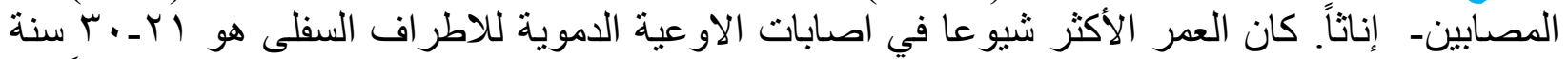

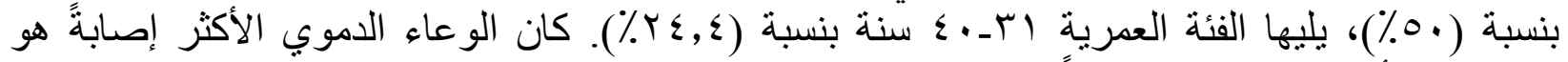

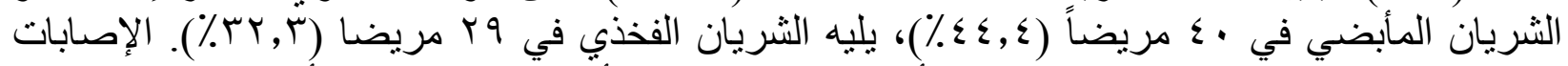

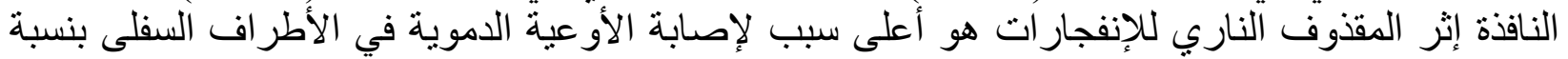

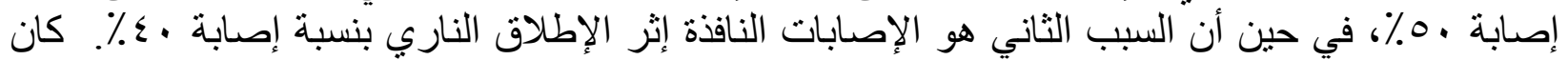

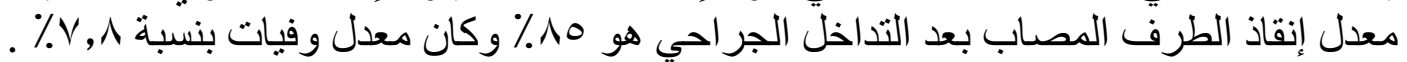

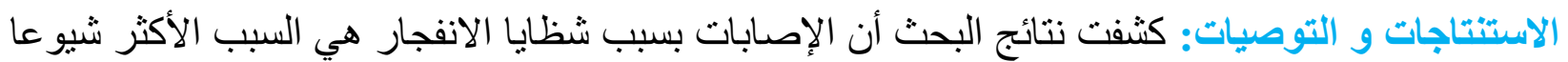

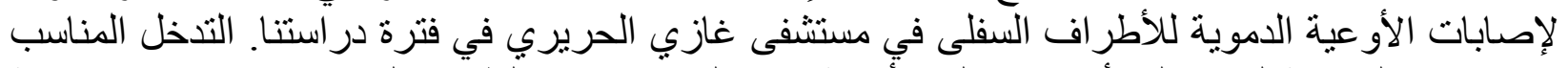

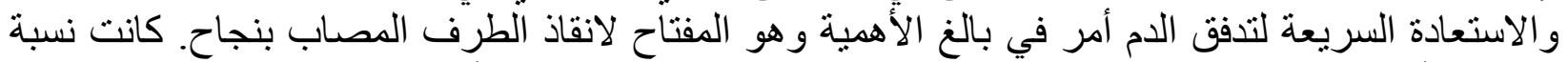

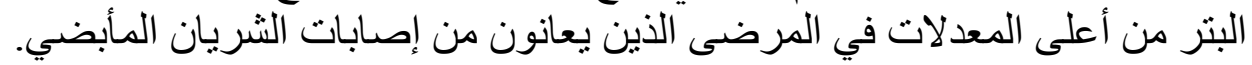

